\title{
$\mathrm{SF}_{6}$ ガス遮断器の高周波電流遮断時のアーク抵抗, アークコンダクタンスの測定方法
}

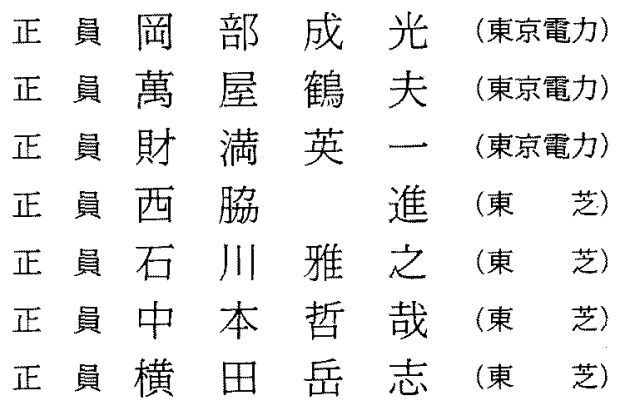

\section{Measurement of Arc Resistance and Conductance during Interruption of High Frequency Current on $\mathrm{SF}_{6}$ Circuit Breaker}

Shigemitsu Okabe, Member, Tsuruo Yorozuya, Member, Eiichi Zaima, Member (Tokyo Electric Power Company), Susumu Nishiwaki, Member, Masayuki Ishikawa, Member, Tetsuya Nakamoto, Member, Takeshi Yokota, Member (Toshiba Corporation)

It is not easy to measure arc voltage of reignition high-frequency current at the time of smallcurrent interruption by a high-voltage circuit breaker because arc voltage is much lower than circuit voltage, and the phenomenon is the high-frequency one. There have been few reports on this type of measurement. This paper mainly describes the measuring methods for the above-mentioned arc voltage. The arc voltage was measured by employing a $300 \mathrm{kV} \mathrm{SF}_{6}$-gas circuit-breaker model in an experimental circuit simulating reignition at the time of reactor-current interruption. Arc resistance and arc conductance were obtained from the measured arc voltage and current. These arc resistance and arc conductance offer the data necessary for clarifying and analyzing reignition surge and high-frequency arc extinction phenomena.

Several methods were employed to measure high-frequency arc voltage. (1) An insulating spacer was utilized as a voltage divider. (2) Clippers were installed for measured signal output. (3) Zero-line shift of voltage-divider output at the time of circuit-breaker reignition was controlled and utilized. (4) Errors due to voltage-divider characteristics included in the original measured waveforms and errors of voltage drop due to stray inductance were corrected. (5) For the above-mentioned correction, a microprocessor was utilized to effect differentiation, integration, and other calculations on waveforms. (6) Signals were optically transmitted.

\section{キーワード：アーク抵抗，アークコンダクタンス, 再発弧, 高周波電流, $\mathrm{SF}_{6}$ ガス遮断器}

\section{1.まえがき}

電力用遮断器で遅れ位相や進み位相の小電流を開閉 する際に開閉サージが発生することがある。遮断の際
に再発弧や再点弧が発生すると高周波のサージが発生 する。

シャントリアクトルに流れる荤れ小電流を遮断する 際のサージ電圧について実測例が幾つか報告されてい 
る。再発弧によるサージ電圧によって避雷器が動作し た例や，再発弧に続いて遮断器極問を流れる高周波電 流を遮断してしまういわゆる高周波消弧による電圧拡 大現象の観測例(1)-(4) がある。

これらサージ現象については解析が行われてい

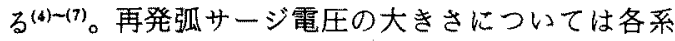
統構成に拈いて計算によって求めている(4)(6)が, 計算 精度の向上のためにはアーク抵抗の情報が必要であ る。高周波消弧についてはMayr 形のアーク動特性 モデルを用いて計算している例があるが(7)，精度向上 のためにはアーク時定数やアーク損失の実測データが 必要である。これらはアークコンダクタンスから求め られる(8)。

再発弧高周波電流に対するこれらアーク抵抗，アー クコンダクタンスの波形を得るためには，再発弧高周 波電流とアーク電圧を測定しなければならない。しか し, 高電圧回路に抢ける高周波の電流, 電圧の測定 や，回路電圧に比べてけた違いに小さなアーク電圧の 測定は容易ではない。従来，これらの測定について発 表された例はほとんどなかった。

著者は, $300 \mathrm{kV} \mathrm{SF} 6$ ガスパッファ形モデル遮断器 を供試して，再発弧を模擬した試験回路を構成し，高 周波電流とそのアータ電圧を測定した。測定に怯信号 の光変換, 信号のクリップ, マイクロプロセッサによ る信号の補正などの方法を用いた。

\section{2. 試 験回 路}

シャントリアクトル電流遮断時の再発弧とその高周 波現象 ${ }^{(4) \sim(6)}$ を模擬して試験回路を構成した。これを 図1 亿示す。

図 1 の試験回路の動作を，図 2 を用いて説明する。 供試遮断器 GCB を閉の状態加開極する。開極動作 と同期して衝撃電圧発生器 IG をスタートする（図 2 の $A$ 点)。コンデンサ $C$ は抵抗体 $R$ を通して充電さ れて $\mathrm{GCB}$ の端子電圧 $V_{\mathrm{GCB}}$ が立上る。このとき $\mathrm{GCB}$ はまだ開極途上であって，電圧 $V_{\mathrm{CCB}}$ が GCB の極間 耐電圧以上となると極間で放電する (図 $20 B$ 点)。 すると，図 1 において C-L-GCBの回路に高周波電 流 $I_{\mathrm{HF}}$ が流れる。更に, IG-R-L-GCB の回路で, IG の電荷が放電され，主として $R$ で決まる疑似直流電 流 $I_{0}$ が GCB に流れる。GCB の電流 $I_{\mathrm{GCB}}$ は $I_{\mathrm{HF}}$ と $I_{0}$ の重畳したものとなる。

図 2 に示す $C$ 点は高周波電流成分 $I_{\mathrm{HF}}$ が減衰して 電流雾線と接する点である。C 点近傍の電流零点で 消弧する場合としない場合とがある。図 2 は消弧した 場合を示している。

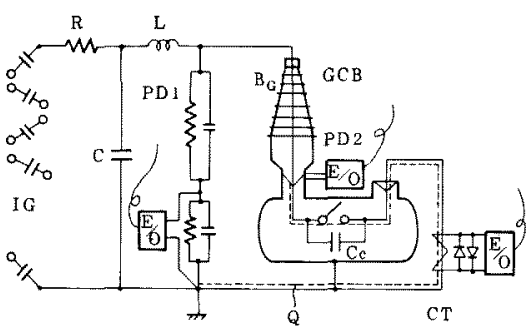

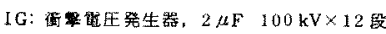

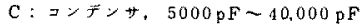
$\mathrm{R}$ : 找抗体， $18 \mathrm{k} \Omega \sim 36 \mathrm{k} \Omega$

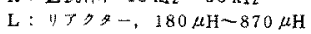

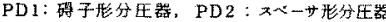

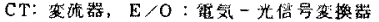

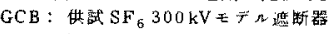

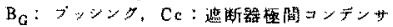

図 1 試験回路

Fig. 1. Test circuit.

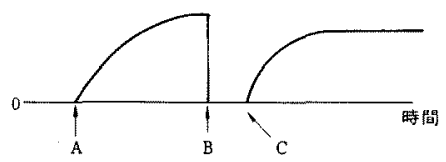

(a) 供試遮断器 $G C B \sigma$ 端子電压 $V_{G C B}$

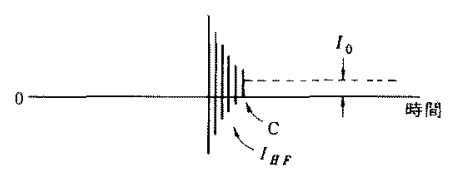

(b) 供試遮断器 GCB 0 䇴流 $I_{\mathrm{CCB}}$

図 2 試験回路における供試遮断器 $\mathrm{GCB}$ の 端子電圧と電流

Fig. 2. Terminal voltage and curret of test circuit breaker GCB in the test circuit.

実際のリアクトル電流遮断に扔ける再発弧の発生, 再発弧高周波電流，再発弧後の交流電流成分および高 周波消弧の発生(4) (6) は, 図 2 において, それぞれ $B$ 点, 高周波電流成分 $I_{\mathrm{HF}}$, 直流電流成分 $I_{0}$ および $C$ 点近傍の現象に対応している。

一方，実際のリアクトル電流遮断においては，遮断 器は開極後いったん数百 $\mathrm{A} の$ 交流りアクトル電流を その電流零点で遮断し, 再発弧はその後, 極間に現れ る過渡回復電圧で発生する。図1の試験回路において は,この数百 $\mathrm{A}$ 程度のアーク電流なしに再発弧する 試験を行うことになる。一般にリアクトル電流遮盺に おいて再発弧する場合はアーク時間が短く，また小電 流アークであるので，再発弧高周波アーク現象に対し て，リアクトルの交流アーク電流の影響は小さいと思 われる。従って，図1に示す試験回路は高周波アーク 
現象に関して等価性は大きいと思われる。

再発弧高周波電流 $I_{\mathrm{HF}}$ の周波数は $275 \mathrm{kV}$ の系統を 模擬した計算例では, $100 \mathrm{kHz}$ 程度またはそれ以上 であることが報告されている(4)(6)。ここでの測定では $I_{\mathrm{HF}}$ の周波数は $27,56,177 \mathrm{kHz}$ の 3 種類とした。直 流分電流 $I_{0}$ についても実系統での現象を念頭におい $\tau^{(6)}, 10 \sim 40 \mathrm{~A}$ とした。

\section{3. 測定方法}

\section{〈3・1〉 アーク電圧の测定}

（1）分圧器の構成図1の試験回路において, GCB のアーク電圧を測定するためには, 遮断器極間 電圧を測定する必要がある。しかし，次のような問題 があった。

（i ）極間には，極間放電前には数百 $\mathrm{kV}$ の電圧が かかり，極間放電後の測定したいアーク電圧は数 $\mathrm{kV}$ である。数 $\mathrm{kV}$ のさなアーク電圧の測定のために分 圧器の分圧比を選定すると，極間放電前の大きな数百 $\mathrm{kV}$ の電圧によって測定系が飽和してしまう。

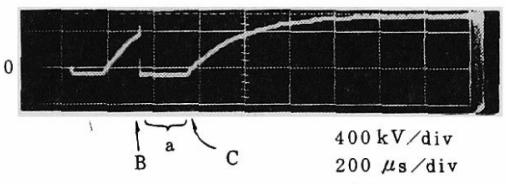

図 $3 \mathrm{GCB}$ の端子電圧 $V_{\mathrm{GCB}}$ の波形例 Fig. 3. Waveform example of GCB terminal voltage $V_{\mathrm{GCB}}$.

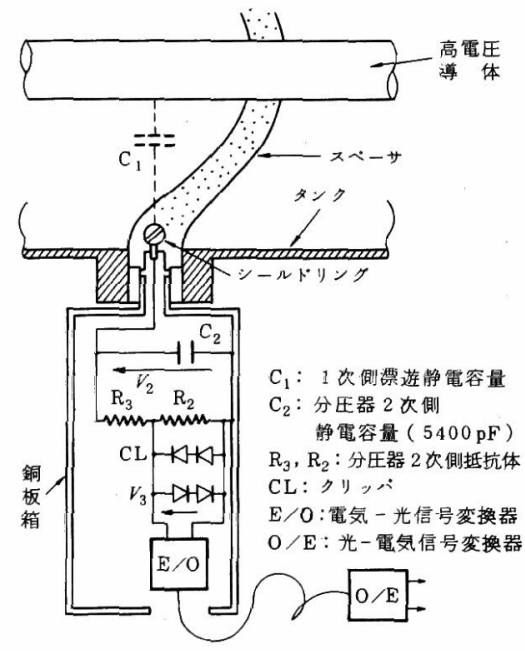

図 4 アーク電圧測定のための分圧器 Fig. 4. Voltage divider for arc voltage measurement.
図 3 は図 1 の試験回路におけるがいし形分圧器 $P D_{1}$ で測定した供試遮断器 GCB の端子電圧 $V_{\mathrm{GCB}}$ の 例である。図 3 は図 2(a) と対応していて, $B$ 点で $\mathrm{GCB}$ の極間が放電し， $C$ 点で高周波電流が消弧して いる。測定しようとしているアーク電圧の範囲は, 図 3 のオシログラムで $B$ 点後のほとんど電圧零である 区間 $a$ の部分である。

（ii）高周波サージ電流を伴った測定であって，ア 一ス電位の変動が大きい。

(iii) アーク電圧は数 $\mathrm{kV}$ と小さい。従って, アー ク電圧に加わって現れる高周波電流回路のインダクタ ンスによる電压降下を無視できない。

上記の問題解決のために，図 4 に示すような高電圧 導体を支える絶縁スペーサを分圧器として利用し, 信 号を光伝送する測定方法を採用した。スペーサの接地 電位タンク側に埋込まれたシールドリングを利用し, 高電圧導体とこのシールドリングとの間の漂遊静電容 量 $C_{1}$ およびシールドリングと接地電位タンクとの間 に接続した二次側静電容量 $C_{2}$ との間で分圧器を構成 する。この分圧器は次の利点を有する。

（i）光伝送方式のために高周波サージ電流による アース電位の変動の影響を抑制することができる。

(ii) 図 1 の. $P D_{2}$ に示すように, ブッシング $B_{C}$ 下部のスペーサを用いて, 測定点を遮断器接点の近く に設置することができるので, 高周波電流回路のイン ダクタンスによる電圧降下の誤差を小さくすることが できる。

図 4 の分圧器において, 分圧比は数 $\mathrm{kV}$ のアーク電 圧測定用にセットした。極間放電前の $500 \mathrm{kV}$ 程度の 大きな電压に対する信号については, クリッパCL によって抑えて $E / O$ 変換器を保護した。 $C L$ は, 逆 回復時間 $2 \mathrm{~ns}$, 端子間容量 $2 \mathrm{pF}$ の高速ダイオード 1S 1585を 2 直列逆並列に接続して構成し，その順方 向電圧を利用した。主回路電圧は一次側漂遊静電容量 $C_{1}$ と二次側静電容量 $C_{2}$ とで分圧され, 更に $R_{2}, R_{3}$ の回路で分圧される。

用いた分圧器の各定数を表 1 に示す。表 1 における

表 1 図 4 に示すスペーサ利用分圧器の定数 Table 1. Constants of spacer type voltage divider shown in Fig. 4.

\begin{tabular}{|c|c|}
\hline 1 次側漂遊静電容量 $C_{1}$ & $1.78 \mathrm{pF}$ \\
\hline 2 次側静笔容量 $c_{2}$ & $5400 \mathrm{pF}$ \\
\hline 2 欢側回路抵抗 $R_{2}=R_{3}$ & $\begin{array}{l}27 \mathrm{kHz} \text { および } \\
56 \mathrm{kHz} \text { の測定のとを } 5.1 \mathrm{k} \Omega \\
177 \mathrm{kHz} \text { の测定のとき } 2.0 \mathrm{k} \Omega\end{array}$ \\
\hline E / OD入力抵抗 & $1 \mathrm{M} \Omega$ \\
\hline
\end{tabular}


一次側漂遊静電容量 $C_{1}$ の值については次のようにし て求めた。図 4 に示す分圧器 $P D_{2}$ において, $R_{2}, R_{3}$, $C L$ を取りはずして， $C_{1}$ と $C_{2}$ だけで分圧器を構成す る。これに，数 $\mathrm{kV}$ で数十 $\mathrm{kHz}$ 数百 $\mathrm{kHz}$ の高周波 電圧を印加して測定する。一方, 分圧比のかかってい るがいし形の $C R$ 分圧器 $P D_{1}$ で同時に振動電圧を測 定して印加電压を求める。 $P D_{2}$ 分王比を $C_{1} /\left(C_{1}+C_{2}\right)$ とし，わかっている $C_{2}$ の值を用いて $C_{1}$ を求める。 その結果 $C_{1}=1.78 \mathrm{pF}$ を得た。

(2) 分圧器の特性 図 4 の分圧器において $C_{2}$ の端子電圧 $V_{2}$ と $E / O$ の入力電压 $V_{3}$ の関係は $(1)$ 式 のようになる。（1）式に扔いて，クリッパダイオード

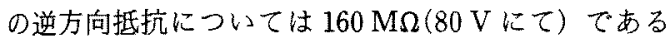
ので無視した。

$$
V_{3}=\frac{\left(R_{2} / / 2 R_{R E} / / R_{E O}\right)}{R_{3}+\left(R_{2} / / 2 R_{R E} / / R_{E O}\right)} V_{2}
$$

ただし， $R_{R E}$ :タリッパ用ダイオードの順方

向抵抗， $R_{E O}: E / O D$ 入力抵抗 $=1 \mathrm{M} \Omega$,

$\left(R_{2} / / 2 R_{R E} / / R_{E O}\right): R_{2}$ と $2 R_{R E}$ と $R_{E O}$ の並列

抵抗

(1)式において，ダイオードの順方向抵抗 $R_{R E}$ は 非直線であるので， $V_{3}$ と $V_{2}$ とが比例関係にあるため には $R_{2} \ll R_{R E}$ でなければならない。図 5 はクリッパ 用ダイオード $1 S$ 1585，1 個の順方向の電圧一電流を 剆定し，抵抗值を求めた結果てある。 $200 \mathrm{mV}$ 以下に おいて $300 \mathrm{k} \Omega$ 程度以上であることがわかる。従っ て,このとき, 表 1 に示す $R_{2}$ は $R_{2} \ll R_{R E}$ を満たして いる。

このようにR $R_{2}$ 小さくしなければならないので， $R_{3}$ も $E / O$ 変換器への入力電圧を確保するためには あまり大きくできない。従って，図2（a）に示す主 回路電圧が分圧器に印加されたとき, 同図に示す $A$ $B$ 間においてはクリッパが動作し， $C_{1}$ と $C_{2}$ とで分 圧されて $C_{2}$ に蓄えられたチャージは， $B$ 点で遮断器 極間が放電する前に，主として抵抗 $R_{3}$ クリッパを通 して一部分放電してしまう。従って, $B$ 点で遮断器 極間が放電して主回路電圧がアーク電圧となってほと んど零となったときに, 分圧器の出力電圧はこのチャ ージの放電分だけ零線を横切ってシフトしてしまう。 シフトして逆方向のクリッパが動作する。この様子を 図6に示す。

遮断器極間放電後の主回路電圧はアーク電圧成分が ほとんどであって小さい。徉って，シフトしてクリッ パが動作した後， $C_{2}$ のシフトしたチャージが主とし て $R_{3}$ ークリッパを通して放電されるにつれて, 出力電 圧はクリッパの動作電圧以下となる。更に $C_{2}$ のチャ

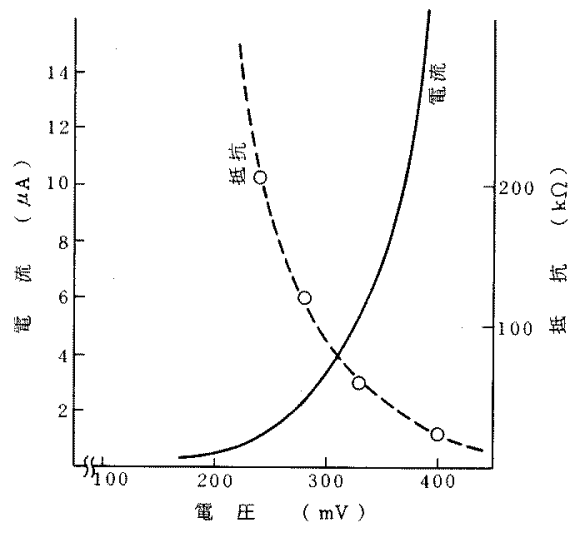

図 5 クリッパとして用いたダイオード 1 個 の順方向の電圧一電流特性扔よび抵抗值

Fig. 5. Forward voltage-current characteristic and resistance value per one piece of diode used for clipper.

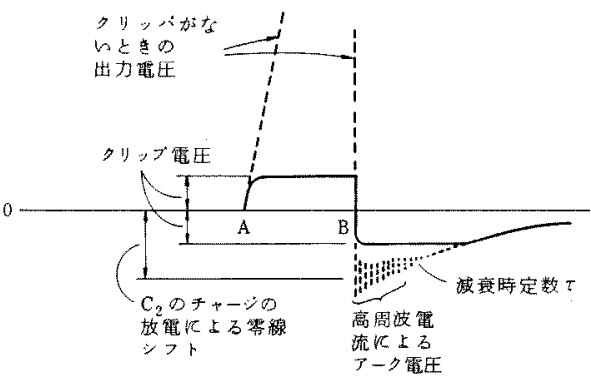

図 6 分圧器出力の零線シフトの説明図

Fig. 6. Explanation diagram for zero line shift of voltage divider output.

一ジは，主として $R_{3}-R_{2}$ を通して放電されるように なり, 出力電圧は零レベルにもどっていく。

図 6 に示すように， $B$ 点で極間放電後の高周波電 流によるアーク電圧の情報は， $C_{2}$ のコトしたチャ ージの放電時定数 $て$ が大きいとクリップされて見る ことができない。そこで，この時定数 $\tau$ を短くして， 高周波電流がまだ継続している間に，クリッパの動作 が終了するようにした。すなわち， $R_{3}, R_{2}$ の值を小さ くして時定数てを小さくした。表 1 に示す $R_{3}, R_{2}$ の 值は，これらのことも考虑して設定したものである。

$\langle 3-2\rangle$ 高周波電流の測定 高周波電流の測定に は図 1 およざ図 7 に示すように，高周波 $C T$ を用い た。CTの出力信号は光変換して伝送した。これによ って,アーク電圧測定と同様に雑音の影響を低隇する ことができた。更に，クリッパCLを用いて，遮断 器極間放電直後の大きな高周波電流信号をクリップし 


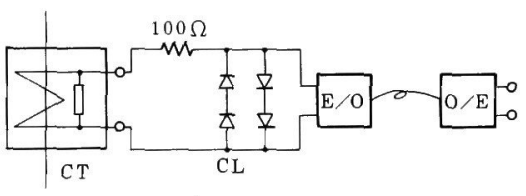

$\mathrm{CT}$ ：高周波変流器， CI：クリッハ

$\mathrm{E} / \mathrm{O}:$ 電気一光信号变換器, $\mathrm{O} / \mathrm{E}:$ 光一電気信号変換器

\section{図 7 高周波電流測定回路}

Fig. 7. Measurement circuit for highfrequency current.

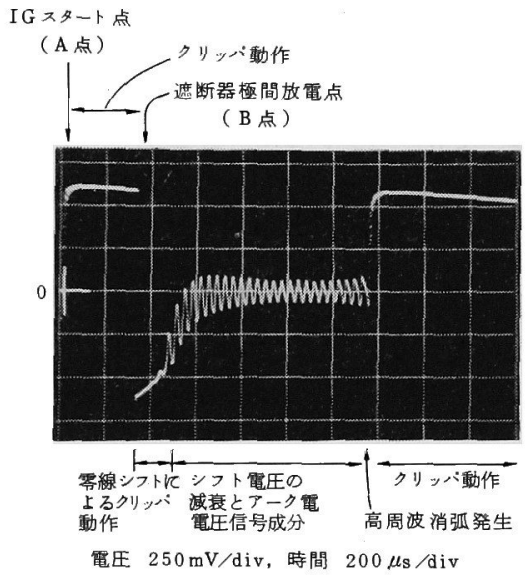

(a) 電圧波形

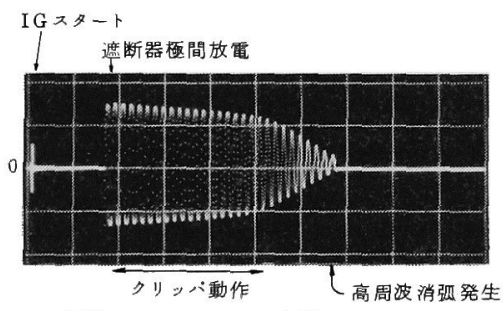

電流： $500 \mathrm{mV} / \mathrm{div}$, 時間 $200 \mu_{\mathrm{s}} / \mathrm{div}$

(b) 電流波形

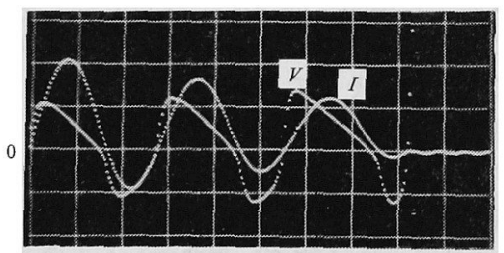

電生 : $62.5 \mathrm{mV} / \mathrm{div}$, 電流 : $125 \mathrm{mV} / \mathrm{div}$ 時間： $12 \mu \mathrm{s} / \mathrm{div}$

(c) 電流電生波形

( a ) ( b ) に抢ける高周波消弧発生近傍

図 8 原測定波形例（電流周波数: $27 \mathrm{kHz}$, 遮断器可動電極ストローク長: $0.21 \mathrm{pu}$ )

Fig. 8. Examples of originally measured waveforms.
た ${ }^{(9)}$ 。これは, 測定したアーク電圧と対応させて, 高 周波電流が減衰した時点での電流信号に測定器の感度 を設定したためである。図 7 に示す高周波電流測定回 路では,クリッパを用いてもく3・1〉節に述べたアーク 電圧測定の場合のような零線シフトの問題は発生しな かった。図 7 における $100 \Omega$ はクリッパ $C L$ が動作 したときの電流制限用である。

用いた高周波 $C T$ の実用立上り時間は $200 \mathrm{~ns}$ であ る。クリッパ $C L$ は図 4 のアーク電圧測定用分圧器 に用いたものと同じものである。

\section{4. 測定波形例}

測定によって得られた原波形例を図 8 , 図 9 に示 す。図 8 は高周波電流の周波数が $27 \mathrm{kHz}$ の場合で, (a) 図は電圧波形である。図6で説明したように, IG のスタート点 ( $A$ 点), 遮断器極間の放電点 $(B$ 点), $A$ 点から $B$ 点に至るクリッパ動作, $B$ 点後の 零線シフトとクリッパ動作, シフト電圧の減衰とアー ク電圧信号成分などが記録されていることがわかる。 (b)図は高周波電流波形である。大きな電流值の領 域でクリッパが動作していることがわかる。(a ), (b)図は高周波電流が減衰した時点で, 高周波消弧 が発生していることを示している。(c)図は高周波消

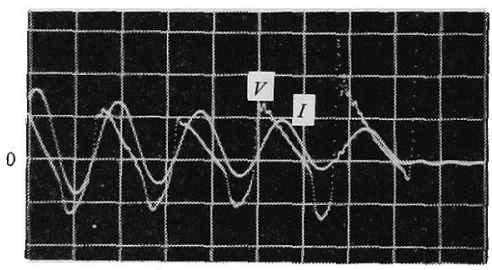

電在 : $100 \mathrm{mV} / \mathrm{div}$ ，電流 : $250 \mathrm{mV} / \mathrm{div}$ 時間： $10 \mu_{\mathrm{S}} / \mathrm{div}$

(a) 電流周波数 $: 56 \mathrm{kHz}$ 遮断器可動電極ストローク長：0.45 pu

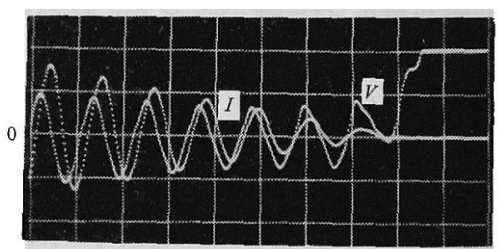

電压： $50 \mathrm{mV} / \mathrm{div}$ ，電流： $200 \mathrm{mV} / \mathrm{div}$ 寺間: $5 \mu \mathrm{s} / \mathrm{div}$

(b) 電流周波数 : $177 \mathrm{kHz}$ 遮断器可動電極ストローク長：0.39 pu

図 9 原測定波形例，高周波消弧点近傍の 時間領域

Fig. 9. Examples of originally measured waveforms. 
弧発生点近傍におけるアーク電圧と電流とを同一画面 上に記録したものである。

更に, 高周波電流の周波数が $56 \mathrm{kHz}$ およよ゙ $117 \mathrm{kHz}$ の場合について, 高周波消弧点近傍におけるアーク 電圧と電流の原測定波形例を図 9 に示す。

図 8, 図 9 における遮断器可動電極ストローク長 は, 可動と固定の両接触子間の金属接触による $0.15 \mathrm{pu}$ 程度のストローク長を含んでいる。

\section{5. 測定波形の補正}

図 8 (c) 扔よび図 9 に扔いて, 高周波電流の零点 とそれに対応するアーク電圧の零点が一致していな い。これは分圧器の特性が原因の誤差, 回路のインダ クタンス電圧降下による誤差が主な原因である。これ らを補正し, また, 実際の電圧, 電流のスケールに変 換した。

〈5・1〉分圧器特性が原因の誤差の補正 〈3・1〉節 に述べたように, 図 4 に示すスペーサ分圧器の二次側 回路の抵抗 $R_{2}, R_{3}$ の值が小さいので, 二次側コンデ ンサ $C_{2}$ の放電時間が短い。従って, 高周波アーク電 圧の測定波形も影響を受ける。これについて補正 した。

図 10 はスペーサ分圧器のアーク電圧成分に対する 等価回路である。遮断器極間放電後の零線シフトが減 衰してクリッパの動作がなくなった後で，しかもクリ ッパ 1 個にかかる電圧が $200 \mathrm{mV}$ 程度以下のときを対 象にしている。このとき〈3・1〉節に述べたように，(抵 抗 $R_{2}$ の值 《クリッパの順方向抵抗) であるので，図 11 ではクリッパを無視している。

図 10 において (2)式および (3)式が成り立つ。

$$
\begin{aligned}
& C_{1} \frac{d}{d t}\left(V_{1}-V_{2}\right)=C_{2} \frac{d}{d t} V_{2}+\frac{V_{2}}{R_{3}+R_{2}} \cdots \\
& V_{3}=\frac{R_{2}}{R_{2}+R_{3}} V_{2}, \quad V_{4}=\frac{1}{k} V_{3} \cdots \cdots \cdots \cdots \cdots
\end{aligned}
$$

(3)式およぴ $R_{2}=R_{3}=R$ を(2)式に用い, ラプラス 変換して整理すると $(4)$ 式を得る。ただし，

$$
\bar{V}_{1}=\left(\frac{C_{1}+C_{2}}{C_{1}}+\frac{1}{S 2 R C_{1}}\right) 2 k \bar{V}_{4}
$$

ここで, $S:$ ラプラス変換演算子, $\bar{V}_{1}, \bar{V}_{4}$ :

$V_{1}, V_{4}$ のラプラス変換

(4) 式は出力電圧 $V_{4}$ から入力電圧 $V_{1}$ を求める関係 式を示している。すなわち $V_{1}$ は (4) 式の第 1 項に $V_{4}$ を乗じて, 更に第 2 項で表される積分補正項に $V_{4}$ を 乗じて, これを加えて得られることを示している。 (4) 式第 1 項は $C_{1}$ と $C_{2}$ で定まる容量分圧比, $R_{2}=$ $R_{3}=R$ で定まる抵抗分圧比および光信号の伝送係数

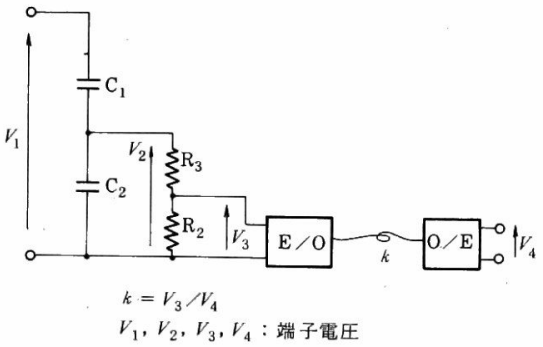

図 10 図 4 亿示す分圧器の等価回路 Fig. 10. Equivalent circuit of voltage divider shown in Fig. 4.

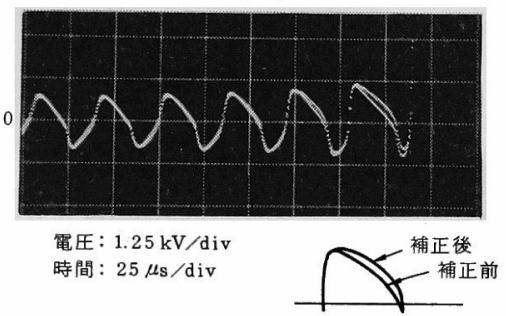

図 11 分圧器特性の補正前後のアーク電圧 の比較例，図 8 のオシログラム $(27 \mathrm{kHz})$

$$
\text { について }
$$

Fig. 11. Comparison of arc voltage between prior and after conducting compensation about voltage divider characteristic.

$k$ とから成っている。

原測定電圧波形を積分して，（4)式に従って補正を 行った。例として図 8 (c) に示した $27 \mathrm{kHz}$ の電圧測 定波形について，（4) 式の積分項の補正を行わなかつ た場合との比較を図 11 に示す。

測定波形の積分, 定数乗算および加算などは測定器 内蔵のマイクロプロセッサを用いた ${ }^{(10)}$ 。

\section{〈5・2〉 回路の漂遊インダクタンス電圧降下の補正}

図 1 に示す回路におけるブッシング下部のスペーサ での測定電圧には，遮断器のアーク電圧だけでなく， 図 1 の破線 $Q$ 部の漂遊インダクタンス電圧降下も含 んでしまう。アーク電圧を求めるために, 測定電圧か らこの漂遊インダクタンス電圧降下を差し引いた。

まず, 図 1 の破線 $Q$ 部のインダクタンスを測定し た。図 1 において，ブッシング頭部で回路を切離して ギャップを設け，遮断器を投入状態にして IG をスタ 一トし，このギャップを放電させて高周波電流を流し た。このときの電圧降下と電流を測定した。この測定 結果から回路の漂遊インダクタンスとして $11 \mu \mathrm{H}$ を 得た。 


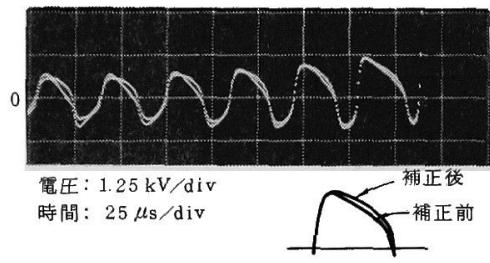

図 12 漂遊インダクタンス電圧降下の補正後 と補正前 $(\langle 5 \cdot 1\rangle$ 節に述べた分圧器特性 補正済）のアーク電压との比較例, 図 9 のオシログラム $(27 \mathrm{kHz})$ について Fig. 12. Comparison of arc voltage between prior and after conducting compensation about stray inductance voltage drop.

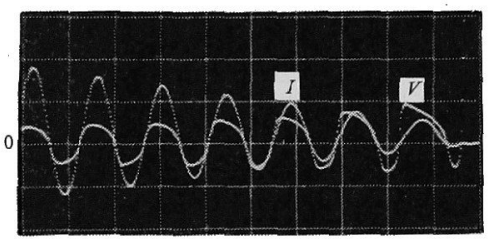

アーク電压 $1.25 \mathrm{kV} / \mathrm{div}$ 電硫

$125 \mathrm{~A} / \mathrm{div}$ 時間 $25 \mu_{s} / \mathrm{div}$

( a ) - アーク電圧, 電流

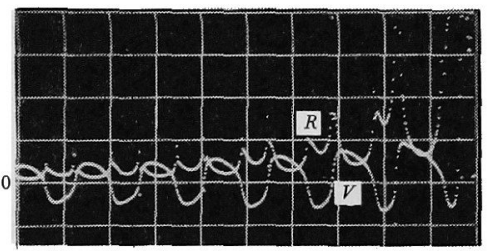

T一ク抵抗 $20 \Omega /$ div 丁 $ク$ 電压 $1.25 \mathrm{kV} / \mathrm{div}$ 時間 $25 \mu \mathrm{s} / \mathrm{div}$

(a )-2 アーク抵抗, アーク電圧

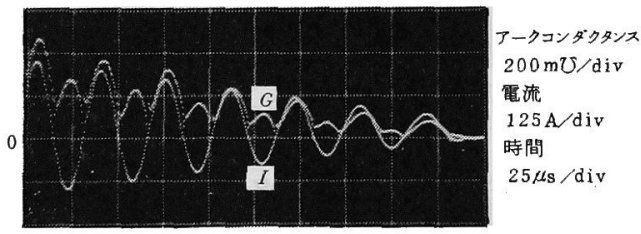

(a) -3 アークコンダクタンス, 電流

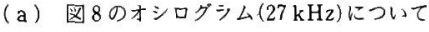

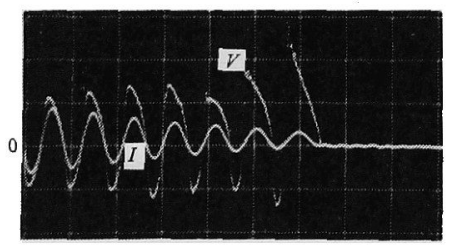

アーク電生

$1 \mathrm{kV} / \mathrm{div}$

電流

$250 \mathrm{~A} / \mathrm{div}$

時間

$20 \mu \mathrm{s} / \mathrm{div}$

(b ) -1 アーク電生, 電流
次に,アーク電圧測定時の電流波形を微分して $11 \mu \mathrm{H}$ を乗じて結果を，〈5・1〉節で述べた分圧器特性 の補正後の測定電圧波形から差し引いた。例として, 図 11 に示した分圧器特性補正だけの波形との比較を 図 12 に示す。

補正のための波形の演算には、ここでも測定器内蔵

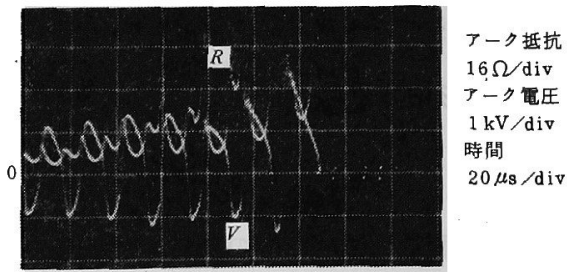

(b) -2 アーク抵抗，アーク電圧

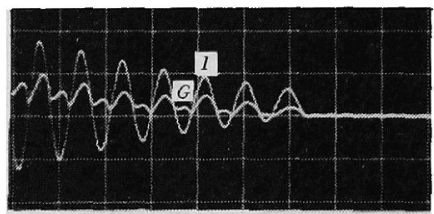

アークコンダクタンス $250 \mathrm{~m} U /$ div

電梳

$125 \mathrm{~A} / \mathrm{div}$

(b) -3 アークコンダクタンス, 電流

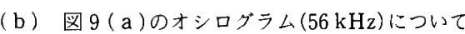

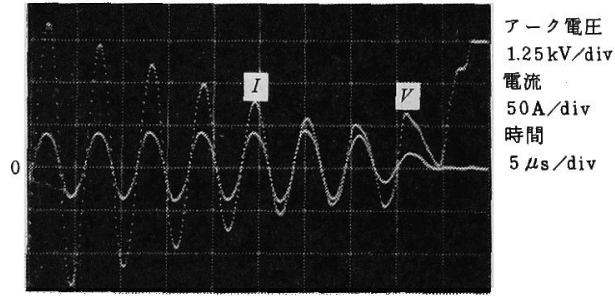

(c) -1 アーク電圧, 電流

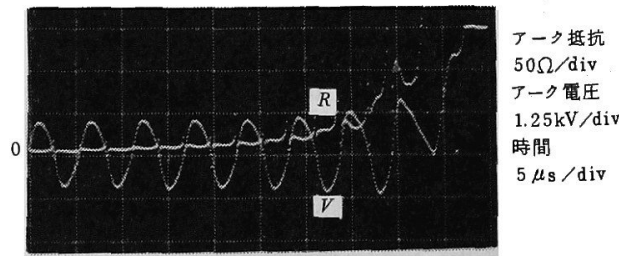

(c) -2 アーク抵抗, アーク電圧

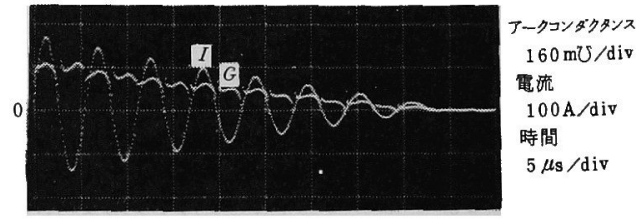

(c)-3 アークコンダクタンス, 電流

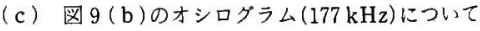

図 13 補正実施後のアーク電圧と電流, アーク抵抗とアークコンダクタンスの算出結果 Fig. 13. Arc voltage and current after conducting compensation, calculated waveforms of arc resistance and arc conductance. 
のマイクロプロセッサを用いた。

\section{6. アーク抵抗, アークコンダクタンスの算出}

図 8 および図 9 に示した，それぞれ高周波電流の 周波数が $27,56,177 \mathrm{kHz}$ の場合の原測定波形例に ついて,〈5・1〉節で述べた分圧器特性に対する補正お よび〈5・2〉節で述べた回路インダクタンス電圧降下に 対する補正を実施した結果を図13(a ) -1，（b ）-1, (c)-1に示す。補正することによって, 高周波電流 の零点とアーク電圧の零点が一致するようになること がわかる。

このように補正して得られた電圧波形と電流波形を 互いに除することによって，アーク抵抗とアークコン ダクタンスとを求めることができる。

図 13(a) -1，（b ) -1，（c）-1 に示す高周波電流と アーク電圧とから算出されたアーク抵抗とアークコン ダクタンスとを各タアーク電圧, 高周波電流と一緒に 図 13 ( a ) -2 , ( ( a ) -3 , ( b ) - 2, ( b ) -3, ( c ) -2 , (c) -3 に示す。このように, 高周波電流の時間変化 の波形に対応したアーク電圧, アーク抵抗，アークコ ンダクタンスの変化の波形を得ることができた。

\section{7. 検討}

図 1 に示すように供試遮断器 GCB の極間にはコン デンサが接続されている。測定された高周波電流には 極間のアーク電流のほかに, このコンデンサや回路の 漂遊静電容量を通して流れる電流成分も含まれる。し かし, 今回の測定ではこの電流成分は, アーク電流成 分に比較して無視できるほど小さかった。

図 14 は, 上記の静電容量電流の補正実施前後の比 較例を示す。図 14 の波形は図 8 と同一試験の波形で あって, 電圧波形は〈5・1〉節およびく $5 \cdot 2\rangle$ 節に述べた補 正を実施した後のものである。（a )図において，D

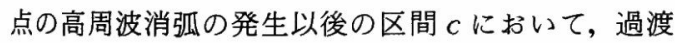
回復電圧に対応して進み位相の電流が観測されてい る。これが上記の静電容量を通して流れる電流であ る。図 14(a)の電圧波形を微分して, 図のcの区間 の電流值に等しくなるように定数を乗じて，これを測 定電流波形から差引いた結果が ( b ) 図である。cの 区間で電流がほとんど零となって補正されたことがわ かる。しかし， bのアーク電流区間の電流波形はほと んど変化がなく，このアーク電流区間の電流に対して は上記静電容量電流の影響はほとんどないことがわ 加る。

図 14 は高周波電流の周波数が $27 \mathrm{kHz}$ の場合であ るが，56, $177 \mathrm{kHz}$ の場合も同様の結果であった。

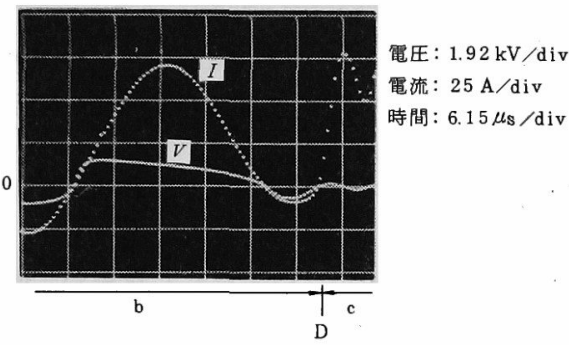

（a）静電容量電流補正実施前

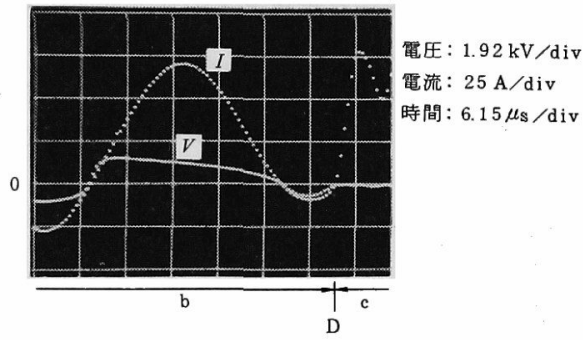

(b) 静電容量電流補正実施後

$D$ : 高周波消弧発生点, $b:$ 高周波アーク電流, アーク電圧区間, $c:$ 過渡回復電圧区間

図 14 静電容量電流補正前後の波形比較

図 8 のオシログラム $(27 \mathrm{kHz})$ について

Fig. 14. Comparison of waveforms between prior and after conducting compensation about capacitance current.

\section{8. まと め}

$300 \mathrm{kV} \mathrm{SF}_{6}$ ガスパッファ形モデル遮断器を供試し て, 再発弧を模擬した試験回路を構成し，高周波電流 とそのアーク電圧を測定した。

アーク電圧測定にあたっては, アーク電圧が回路電 圧に比べてけた違いに小さいことや，高周波現象のた めに, 次のような方法を用いた。

（1）アークの発生する遮断器接点近傍に設置した 絶縁スペーサを分圧器の静電容量として用いて, 漂遊 インダクタンス電圧降下による測定誤差を小さく した。

（2）分圧比を低いアーク電圧測定用に設置した。 従って, 高電圧に対する大きな分圧器出力から測定器 を保護するためにクリッパを設けた。

（3）分圧器二次側コンデンサの電荷のディスチャ ージが原因の分圧器出力電圧の零線シフトをコントロ ールし，これを利用した。

（4）原測定波形に含まれる分圧器特性が原因の誤 差を補正した。

（5）原測定波形に含まれる回路の漂遊インダクタ 
ンスによる電圧降下が原因の蕠差を補正した。

（6）上記（4)，（5 ) の補正にあたっては, 波形測 定器内蔵のマイクロプロセッサを用いて, 波形の積 分, 微分, 加減乗除を行った。

（7）測定信号の光伝送を行って，アース電位の上 昇などによる雑音の影響を小さくした。

高周波電流の測定には高周波 $C T$ を用い, 信号を 光伝送した。

測定で得られた高周波電流とアーク電圧を互いに除 することによってアーク抵抗とアークコンダクタンス を求めた。

このような測定方法によって，再発弧サージや高周 波消弧現象の解明，解析に必要なデータを得ることが できる。

(平成 2 年 11 月 16 日受付)

\section{文献}

(1) S. H. Sarkinen, G. G. Schockelt \& J. H. Branke: "High Frequency Switching Surges in EHV Shunt Reactor Installation with Reduced Insulation Levels", IEEE Trans. Power Apparatus Syst., PAS-98, 1013(1979)

(2) K. Nakanishi, M. Ishikawa, Y. Abe, K. Andoh, S. Yanabu, A. Ohnuma \& Y. Kurosawa: "Small Current Interruption Phenomena and Recent Progress of Gas Circuit Breaker", CIGRE 1988, 13-06

( 3 ) K. Möller, A. Claudi, H. H. Schramn, B. Stößer, A. Strnad, T. Weinmann \& K. H. Hinterthür: "Characteristics of Gas Blast Circuit-breakers Influencing Reignitions When Interrupting Small Inductive Currents", ibid., 13-15

(4) H. Kawada, K. Goto, M. Hanamura, S. Yanabu, S. Nishiwaki, T. Ueda \& Y. Murayama: "Switching Surge of Shunt Reactor Caused by $\mathrm{SF}_{6}$ Circuit Breaker Operation". IEEE Trans. Power Delivery, PWRD-2, 1124(1987)

（5）花村・萬屋・岡部・石川・西脇・柳父：「ガス遮断器による リアクトル開閉に伴う現象」, 電気学会開閉保護装置研資, SPD-89-3 (平元)

(6) E. Zaima, S. Okabe, S. Nishiwaki, M. Ishikawa, T. Nakamoto, Y. Murayama \& Y. Kawaguchi :"Reignition Surges at Reactor Current Interruption in Cable-system GIS", IEEE Trans. Power Delivery, PWRD-5, 947(1990)

（7）佐久間・山本・中村・米沢・細見：「遮断器の小電流開閉の 検討」, 電気学会開閉保護装置研資, SPD-88-5 (昭 63)

(8) E. Anke: "Ein modifiziertes Verfahren zur Bestimmung der Lichtbogenparameter nach der Methode der Stromüberlagerung", Electrie, Berlin 9. 38, 9, 328(1984)

(9) K. Nojima, S. Nishiwaki, H. Okubo \& S. Yanabu, "Measurement of Surge Current and Voltage Waveforms Using Opticaltransmission Technics", IEE Proc., Pt. C, 134, 415 (1987)

(10) “Nicolet Oscilloscope 4094 Math Package", Manual, Nicolet

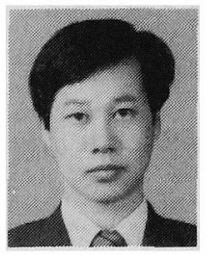

\section{岡 部 成 光 (正員)}

昭和 33 年 9 月 18 日生。 41 年東 京大学大学院博士課程修了。 61 年 東京電力 (株) 入社。主として, 絶縁 協調の研究に従事。

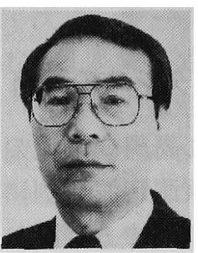

萬 屋 鶴 夫（正員）

昭和 17 年 10 月 8 日生。 36 年小 松実業高校卒業。同年, 東京電力 (株) 入社。主に変電所設計，技術開 発に従事。

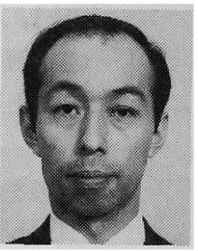

財 满 英 一（正員）

昭和 24 年 10 月 28 日生。 49 年東 京大学卒業。同年(株)東京電力入 社。平成 2 年 MIT 修士。主とし て, 変電技術, 絶縁協調に従事。

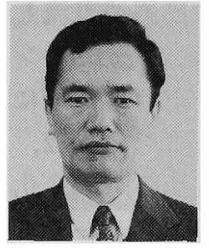

\section{西脇進（正員）}

昭和 22 年 1 月 3 日生。 44 年 3 月 横浜国立大学工学部卒業。同年 4 月 (株) 東芝入社。避雷器, 開閉保護装 置, サージ現象などの研究開発に従 事。工学博士。5 8 年電気学会論文賞受賞。IEEE 会員。

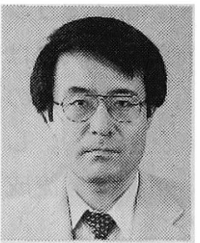

\section{石 川 雅 之（正員）}

昭和 28 年 8 月 27 日生。 56 年 3 月慶応義塾大学大学院博士課程修 了。同年 4 月 (株) 東芝入社。 $\mathrm{SF}_{6}$ ガ ス遮断器の遮断現象および機器の開 発に従事し，現在に至る。IEEE 会員。

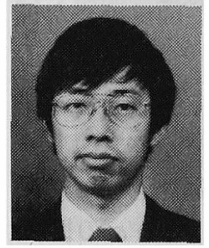

中 本哲 哉 (正員)

昭和 32 年 2 月 4 日生。 56 年 3 月 京都大学大学院電気工学専攻修士課 程修了。同年 4 月 (株) 東芝入社。浜 川崎工場において, ガス遮断器の開 発・設計に従事。

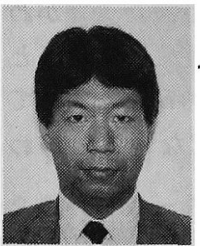

\section{横 田 岳 志（正員）}

昭和 33 年 2 月 15 日生。 57 年横 浜国立大学大学院修士課程修了。同 年(株) 東芝入社。本社電力変電技術 部において, 主に変電機器, 開閉装 置の開発システム技術に従事。 